\title{
Issues at the Rural-Urban Fringe: Land Use Conflicts ${ }^{1}$
}

\author{
Rodney L. Clouser ${ }^{2}$
}

\section{Introduction}

Florida's rapid population growth over the last four decades is well documented. State population increased from 4.9 million in 1960 to 15.9 million in 2000 (Population of Counties by Decennial Census: 1900 to 1990 and 2000). These last four decades have taught Florida politicians, businesses, and residents many valuable lessons. Among the lessons learned is that resource competition and land use conflicts arise when you more than triple the population base.

The purpose of this fact sheet is to discuss some of the issues that contribute to conflicts by examining both the rural and urban perspectives of the issues. Land use conflict issues at the rural-urban fringe can be grouped into three categories: (1) lifestyle issues, such as odors, noise, etc.; (2) infrastructure; and (3) property rights and wealth distribution. The issue of urban sprawl into rural areas is not a new issue in the United States and it will most likely continue for some time to come.

\section{Lifestyle Issues}

Two of the most common complaints of urban residents living close to agricultural production areas are odors and noise. Nostalgic pastoral images of rural life are just that: images. A real farm is a working business that creates noise and unpleasant odors. Many urbanites moving to rural areas often comment "it did not smell like this when I purchased my lot or house, so the producer must be doing something different," or "there was no noise coming from that farm when I looked at this lot or house." That may indeed be true, but the implication that the farmer/producer is doing something different or may be in the "wrong" is not correct either. The old housing market proverb "buyer beware" certainly holds true if you plan to purchase a lot or house next to, or near, a producing agriculture operation. Good advice for those moving to rural areas is to visit the site many times, under differing wind patterns and weather conditions, before making a purchase. Better yet, visit the farmer/producer and ask what types of agricultural operations occur on the farm property. Florida has a Right-to-Farm law (Florida Statutes, Section 823.14) that basically establishes that a farm in operation for at least one year, that was not considered a nuisance when established, using generally accepted agriculture practices cannot be considered a nuisance. Always check the rules before buying so there are no unpleasant surprises. For more information, see EDIS

1. This is EDIS document FE549, a publication of the Department of Food and Resource Economics, Florida Cooperative Extension Service, Institute of Food and Agricultural Sciences, University of Florida, Gainesville, FL. This document is one of a series entitled "Issues at the Rural Urban Fringe". Published May 2005. Please visit the EDIS website at http://edis.ifas.ufl.edu.

2. Rodney L. Clouser, Professor and Public Policy Specialist, Department of Food and Resource Economics, Florida Cooperative Extension Service, Institute of Food and Agricultural Sciences, University of Florida, Gainesville, FL.

The Institute of Food and Agricultural Sciences (IFAS) is an Equal Opportunity Institution authorized to provide research, educational information and other services only to individuals and institutions that function with non-discrimination with respect to race, creed, color, religion, age, disability, sex, sexual orientation, marital status, national origin, political opinions or affiliations. U.S. Department of Agriculture, Cooperative Extension Service, University of Florida, IFAS, Florida A. \& M. University Cooperative Extension Program, and Boards of County Commissioners Cooperating. Larry Arrington, Dean 
publication FE550, Issues at the Rural-Urban Fringe: Florida State Laws Related to Land Uses (http://edis.ifas.ufl.edu/FE550).

In general, the larger the livestock herd is, the greater the probability that odors may be a concern. However, the smell generated by a small number of horses, cows, goats, etc. may also be untolerable. Producers will argue that these odors are typical agricultural production by-products. They have no control over wind, humidity, or weather conditions. In general, producers follow standard or best farm management practices that keep odor problems to a minimum. There are also state, county, and local governmental regulations regarding this problem.

Noise issues may not be as significant as issues with odors but still may prove problematic. In some instances, noise and odor issues cannot be separated, such as in the case of aerial or field spraying. The airplane or farm equipment makes noise and the sprays generate odors. Wind drift from field spraying may also create concerns regarding the safety of the chemicals being used in agricultural areas. Producers often argue that drift complaints are atypical because most of the chemicals are contained to the fields where they are being used. Another noise problem is the operation of farm equipment late at night and early in the morning when homeowners are trying to sleep. While some individuals may object to the time of day when agricultural equipment is being used, these noises are typical farm production noises and are commonplace, especially during planting and harvesting times.

A related issue is pests, specifically flies and mosquitoes. Concerns with diseases carried by flies and mosquitoes have increased over time. Neither group wants these pests around, so chemical and biological pest control are used to control the problem.

\section{Infrastructure Issues}

Conflicts related to infrastructure (roads, crime protection, waste management, etc.) are a major concern of both rural and urban households. Typically, infrastructure improvements lag behind home construction. Households may spring up rapidly, but it may take several years to secure funding for new roads, police protection, recycling programs, etc.

Roads and traffic congestion on the rural-urban fringe typically are major concerns. Roads become congested from traffic problems created by the growth in home construction and from slow-moving farm machinery and trucks. In addition, while slow-moving, large-sized farm equipment mixed with heavy traffic creates an unsafe driving environment, how else are producers supposed to get machinery from place to place or get their products to market? Until the road infrastructure is upgraded to handle the increased growth both groups must learn to co-exist.

Both producers and landowners are concerned about crime, vandalism, trespassing, and urban-related waste issues. In general, crime in rural areas tends to be property-related, not people-related. At the top of the property-related crime list are trespassing and vandalism, which increase legal liabilities for rural landowners. Injuries or death could result in large claims against the landowner. Even if the landowner is not found liable, hiring attorneys, going to court, etc. are time-consuming and expensive.

\section{Property Rights and Wealth Distribution Issues}

Urban dwellers see living in a rural area as a chance for achieving the "American dream" by owning their own home at a reasonable price and escaping crime and traffic gridlock. While potential land use conflicts are frequently overlooked, issues related to property rights and wealth distribution are often ignored, pitting rural producers and landowners against each other.

While issues related to urban sprawl and the cost of service provisions for outlying developments cost everyone and cannot be overlooked, they may not be an important issue to rural landowners. In many instances cities, towns, and counties have approved the development of some properties while rejecting the development of similar and close proximity pieces of property. One landowner is allowed to use "development rights" while another landowner is not. This may be due to lack of planning and zoning or amendments to already existing land use plans. 
Approving some development rights while denying others can create problems. Approval or denial can cause large shifts in wealth distribution among landowners. For example, based on a 100-acre property, individuals denied development rights would have land assets valued at only $\$ 100,000$ while those approved for development rights may have land assets valued in excess of $\$ 1$ million. Those denied development rights often view those approved for development rights as receiving unfair "windfall" gains, leading to issues related to fairness, arbitrary decisions by government bodies, equity (equal treatment of equals), and equality (equal treatment of all landowners).

\section{Summary}

Landowners, communities, towns, counties, etc. have been slow to recognize and eliminate problems related to growth at the rural-urban fringe. Similar problems have been raised for the past 50 years. Understanding and planning for these conflicts are best handled upfront or before growth at the fringe is underway. Of course, it needs to be remembered there are two sides to all land-use conflict issues and it is no different at the rural urban fringe. Future fact sheets will explore programs adopted in Florida and in other areas of the country to address land use conflicts at the rural-urban fringe.

\section{Further Reading}

Chase, Rick, and Hutcheson, Scott. 1998. The Rural/Urban Conflict. ID-221, Indiana Cooperative Extension Service, Purdue University, West Lafayette, IN.

Edelman, Mark, Jon Roe, and David Patton. 1999. Land Use Conflict: When City and Country Clash. Kettering Foundation, Dayton, $\mathrm{OH}$.

Mulkey, David, and Rodney L. Clouser. 1986. Maintaining Land for Agriculture: A Policy Overview. Food and Resource Economics No. 27, Florida Cooperative Extension Service, University of Florida, Gainesville, FL. 